\title{
THE IMPLEMENTATION EFFECTIVENESS OF HOSPITAL RESPONSIBILITY TOWARDS MEDICAL DISPUTE PROCESS AT HOSPITAL X CIBINONG
}

\author{
Adelin Litan ${ }^{1}$ \\ Esa Unggul University \\ adelinlitan@gmail.com \\ Fresley Hutapea ${ }^{2}$ \\ Esa Unggul University \\ Rina Mutiara ${ }^{3}$ \\ Esa Unggul University
}

\begin{abstract}
Medical disputes that are rife in the medical world in Indonesia are a separate burden for medical personnel in carrying out daily practices, where the hospital as a place for medical personnel to work, should be responsible for medical personnel involved in medical disputes. The absence of sufficiently clear regulations governing the responsibility of hospitals in resolving medical disputes, makes medical personnel, in this case, the most disadvantaged part. The purpose of this study is to empirically determine the applicable laws and regulations regarding the responsibility of hospitals in the process of resolving medical disputes and the effectiveness of their implementation. The research method used is qualitative research with case study approach. Data sources are primary and secondary data. The data analysis subjects were informants, namely the director of medical services, the legal department officer and the public relations officer. The analysis tool uses interactive analysis. There were at least 4 laws and regulations related to hospital responsibility for medical personnel and implementation of regulations regarding hospital responsibility towards medical dispute process is $88 \%$. The research found no guidelines for handling medical disputes. This study shows that the laws and regulations related to hospital responsibility and their implementation in the medical dispute resolution process have been implemented. The recommendation to Hospital X Cibinong is to make guidelines on the flow of medical dispute handling and provide education about health law to all hospital staff, especially medical personnel as parties most vulnerable to malpractice suits.
\end{abstract}

Keywords: Healthcare Worker, Hospital, Medical Dispute Resolution, Responsibility. 


\section{A. Introduction}

In recent years, it has been widely reported in the national media, both through electronic media and print media, that there are many malpractices committed by Indonesian doctors. According to a report by the Central Health Legal Aid Institute (LAI), there were approximately 405 malpractice cases in Indonesia, of which 73 cases were reported to the police (Kusumaningrum, 2016). Another source mentions that there were cases of suspected malpractice during the period 2006 to 2015, there were 317 cases of suspected malpractice reported to the Indonesian Medical Council (KKI), 114 of which were general practitioners, followed by surgeons 76 cases, doctors obsgyn (gynecologist) 56 cases and specialist doctors. child 27 cases (Trisnadi, 2017). Medical accidents can occur due to medical malpractice or a medical risk. Malpractice occurs due to errors or negligence of doctors in carrying out medical actions and doctors do not carry out their profession according to medical service standards. In medical risks, doctors have performed medical services according to standards but there are risks to medical services, such as side effects of a drug or hypersensitivity reactions to certain drugs. (Handayani, 2014)

In the medical dispute between a patient named DS against Hospital $X$ at the Cibinong District Court, in this case the plaintiff was the patient himself while the defendant was the director of hospital X as Defendant I, a specialist in obstetrics and gynecology as Defendant II, and the Minister of Health as a co-defendant. The lawsuit filed by the attorney of DS to the Cibinong District Court which examined and adjudicated this case was not only a matter of material loss but also demanding immaterial losses. However, after 13 months of case examination without going through internal mediation with a total of 23 trials, finally the judge through the Cibinong District Court decision with case number: xxx / Pdt.G / xxxx / PN Cbi decided that the DS lawsuit was unacceptable.

It can be imagined that the doctor concerned who was a defendant in this case had to undergo 13 months with 23 trials with feelings of anxiety, anxiety, depression, fear, or even trauma in handling the patient. Not to mention the costs and time wasted during the process and a tarnished reputation if the coverage of the case is exaggerated. This of course can be very detrimental to the doctor because he has to bear all the burdens, especially if the decision states that there is no element of medical negligence from the doctor concerned. Reflecting on this case, the involvement of the hospital in facilitating the legal process for hospital staff is very important considering that one of the defendants was a doctor who was actually a medical staff at the hospital. Such a 
complicated legal process takes time and costs and damages the reputation of the defendant, it can cause a decline in the doctor's performance in providing medical services according to standards. (Njoto, 2011)

Law Number 44 Of 2009 Article 46, concerning on Hospitals, stated that Hospitals are legally responsible for all losses incurred as a result of negligence committed by health workers at the Hospital (Pemerintah, Undang-undang (UU) No. 44 Tahun 2009 Tentang Rumah Sakit, 2009). However, the elaboration of the extent to which legal assistance is provided is not explicitly detailed, plus the sound of the article can cause confusion because it appears to be siding with medical personnel despite their negligence. Then in Law Number 36 Year 2009 concerning Health, it only states that health workers are entitled to compensation and legal protection in carrying out their duties according to their profession (Pemerintah, Undang-undang (UU) No. 36 Tahun 2009 Tentang Kesehatan, 2009). However, the Law also does not clearly indicate the role of hospitals in providing legal protection for medical personnel in the event of a medical dispute. The purpose of this study is to obtain empirical evidence regarding the responsibility of hospitals in the process of resolving medical disputes.

\section{B. Method}

This research was conducted at the Hospital $X$ Cibinong, a private hospital. This research was conducted from July 2020 to August 2020. The Hospital X Cibinong was chosen because there have been medical dispute at the Hospital. Activities carried out in the form of primary and secondary data collection through literature study and also through questionnaires and interviews. In-depth interviews were conducted with 3 informants consisting of management, namely the hospital medical services' director and hospital's public relation officer as well as the legal department officer.

This research is a qualitative research with a normative and empirical approach. The results of data collection will then be analyzed with the Analysis Interactive Model from Miles and Huberman. Where the steps in data analysis include data collection, data reduction, data display, and conclusions.

Data collection techniques in this study uses questionnaires and also interviews. The results of the questionnaire were formed using the Guttman scale. This scale is a scale that is firm and consistent by providing firm answers such as answers to questions: yes and no, positive and negative, agree and disagree, right and wrong. The Guttman scale is generally made like a checklist with an interpretation of the assessment, if the 
score is a yes the value is 1 and if the score is a no, then the value is 0 (Hidayat, 2007). After scoring, the question is calculated by means of a percentage (\%) of the answer to the question, to find out the knowledge of the respondent. by using absolute criteria:

$$
P=a / b \times 100 \%
$$

Explanation:

P: Percentage

a: Number of 'yes' answer

$b$ : Sum of all questions

After obtaining the results by means of calculations as described above, the final value is interpreted by the criteria of Dean J Champion: (Champion, 1981)

Table 1. Percentage with criteria for Dean J Champion.

\begin{tabular}{|c|c|}
\hline Interval Coefficient & Effectiveness \\
\hline $0-25 \%$ & Very ineffective \\
\hline $25-50 \%$ & Ineffective \\
\hline $50-75 \%$ & Effective \\
\hline$>75 \%$ & Very effective \\
\hline
\end{tabular}

By means of Interviewing so that the data collected later becomes more complete. It is deemed necessary to hold an interview guided by a compiled list of interviews as well as a form of dialogue with the hospital. The interview technique that will be used is the in-depth interview technique or what is often known as the in-depth interview. Indepth interview is a process of digging information in depth, openly, and freely with problems and research focus and directed at the research center. In this case the indepth interview method is carried out with a list of questions that have been prepared in advance (Moleong, 2007). The research instruments in the form of questionnaires and interview guidelines have also been validated with Expert Judgment by the Director of Hospital A, the Director of Hospital S, and the Doctor of Law at University B. With regard to the validity of the data, in this research triangulation has also been carried out with sources triangulation and method triangulation.

\section{Finding and Discussion}

\section{Finding}

a. Implementation of Hospital Responsibilities

1) Hospital Responsibilities In Providing Legal Protection 
Through Law Number 44 of 2009 concerning Hospitals, it is known that there is an obligation for hospitals to protect and provide legal assistance to all hospital officers when they carry out their duties at the hospital. This is confirmed again in Article 46 which states that all losses caused by negligence of health workers are the legal responsibility of the Hospital. In addition, the obligation to provide legal protection is also stated in Article 36 of 2014 concerning health workers (Pemerintah, Undang-Undang (UU) No. 36 Tahun 2014 Tentang Tenaga Kesehatan, 2014). which states that medical personnel in hospitals are entitled to legal protection as long as they perform their duties according to professional standards, hospital service standards, and Standard Operating Procedures.

The results of the questionnaires and interviews indicate that the hospital $X$ Cibinong has carried out its obligation to provide legal protection to medical personnel in carrying out their duties according to their profession. This is supported by the existence of an article in the cooperation agreement between hospitals and medical personnel that the hospital and medical personnel have an obligation to protect and provide legal assistance for hospital officers in carrying out their duties.

2. Legal Protection Related To License For Medical Practice

One of the responsibilities of hospitals in order to provide protection in the realm of administrative law, one of which is the completeness of SIP for medical personnel. So in accordance with Law Number 36 of 2014 concerning Health Workers, it can be seen that every health worker who practices in the field of health services is required to have a license that is granted in the form of a Practice License $(\mathrm{PL})$ which will only be given if he has a Registration Certificate (RC) which is still valid, recommendations from professional organizations and also places of practice. Health workers who do not have PL and RC can also be subject to a maximum fine of Rp. 100,000,000.00 (one hundred million rupiah) without imprisonment.

Based on the results of questionnaires and interviews, it was found that the hospital did provide health services in accordance with professional ethics and operational standards. Then from the results of interviews and questionnaires, data collection was carried out through documentation studies to support the research results and the results were obtained by medical personnel having practice licenses in accordance with legislation.

It can be seen that medical personnel at Hospital $X$ are already required to have $\mathrm{PL}$ with the following requirements. This is evidenced by the data obtained through 
documentation studies where there is an SPO for medical personnel admission which includes the admission of medical personnel starting from the entry of application letters and $\mathrm{CV}$ s, to the credential process to ensure qualifications are in accordance with those required by the hospital.

\section{Legal Protection Related To Standard Medical Procedures}

The rights of health workers also state that health workers are entitled to obtain legal protection as long as they carry out their duties in accordance with the Professional Standards and Professional Service Standards set by professional organizations and Standard Operating Procedures set by health service facilities. And in the event that the provision of services is not in accordance with the standard, the patient has the right to file a lawsuit and or demands against the hospital and not the health worker.

Based on the results of interviews and questionnaires, it can be concluded that medical action in this case has been carried out based on professional standards, hospital service standards, and Standard Operating Procedures (SOP) that apply at RS T Cibinong. This is also supported through documentation studies where there is medical record data which contains records of medical actions carried out in accordance with the procedure. With this, the hospital is obliged to provide legal protection and assistance because the medical personnel in this case have already performed medical actions in accordance with the SOP in accordance with professional standards and service standards regulated in accordance with government recommendations.

4. Hospital Responsibilities In Technical Handling Of Medical Disputes

Through Minister of Health Number 4 of 2018 Regulation concerning Hospital Obligations and Patient Obligations (Kesehatan, 2018), it can be seen that it is the hospital's responsibility to protect and provide legal assistance in the event of a medical dispute or dispute. The hospital's obligations in the event of a medical dispute include providing legal consultation, facilitating mediation and judicial processes, providing legal advocacy, providing an assistance in medical dispute resolution, and allocating a budget for funding the legal process and compensation.

Based on the results of interviews and questionnaires, it can be concluded that Hospital X Cibinong have done most of their obligations in the event of a medical dispute except for allocating a budget for compensation. Regarding the compensation, the hospital transfers the burden to professional insurance whose premiums are paid by the medical personnel concerned, and regarding compensation, the hospital prioritizes funding from the professional insurance and is ready to pay for the shortfall if the claim 
for compensation exceeds the insurance ceiling amount. This is also recorded by the study of documentation and data collection, namely the articles of the cooperation agreement which oblige every medical worker to have professional insurance where the premium is paid by the medical personnel concerned.

b. Implementation of Legislation Regulations Relating to the Responsibility of Hospitals Towards Healthcare Workers in the Process of Medical Dispute

To see the implementation of hospital responsibility towards healthcare workers in the process of medical dispute is measured using the Guttman scale, which basically uses a questionnaire distributed to respondents to get the value of each question. The form of this questionnaire is made in 2 forms of answers. The answer "Yes" states that implementation is going well, while the answer "No" states that implementation has not been going well.

"Yes" answers have a value of " 1 " and for "No" answers have a value of " 0 ". Based on the results of the tabulation of the questionnaire from the informants using the Guttman scale, $X$ answers "Yes" were obtained, while "No" answers were obtained as many as $X$.

Based on this data, the level of implementation obtained is:

$$
\begin{aligned}
\text { Percentage } \%=\mid \frac{\sum \text { Number of Yeses }}{\sum \text { Number of Questionnaires }} \times 100^{\prime} \\
\text { Percentage } \%=\mid \frac{66}{75} \times 100 \\
=88 \%
\end{aligned}
$$

Judging from the results of the above calculations, the implementation of government regulation policies is $88 \%$, although it is included in the very effective category, it is still not perfect because it does not reach $100 \%$, because there are still $12 \%$ of the questionnaires that are not answered by informants.

\section{Discussion}

Hospital $X$ has shown its responsibility towards medical personnel in the process of resolving medical disputes. This is evidenced from the results of interviews, documentation studies and questionnaire measurements, the result is $88 \%$. However, there are some things that are still lacking, for example the absence of SOP for handling medical disputes at $X$ Hospital including internal mediation guidelines at the hospital, a lack of education regarding health law to medical personnel so that when a dispute occurs, the medical staff becomes anxious and feels uncomfortable in undergoing it. daily 
practice, apart from that the hospital has not made full efforts in prioritizing mediation as an alternative to solving medical disputes. Even in the trial process, the court for the medical dispute resolution process xxx / Pdt.G / xxxx / PN Cbi is still a general court and not a special court. However, regarding the provision of legal consultation, facilitating the mediation process and judicial process, providing legal advocacy and providing assistance in the resolution of medical disputes has been carried out well by Hospital $\mathrm{X}$ Cibinong, it's just that the medical personnel liability insurance premium is fully paid by the medical personnel concerned. Rely on Defendant II's professional insurance to pay compensation where it should be the responsibility of the hospital. It would be even better if the hospital provided a special budget for funding compensation or financing for the professional insurance policy of each medical staff at Hospital X.

\section{a. Theoritical Implications}

In setting policies, the hospital applies the theory and legislation related to the hospital's responsibility for medical personnel. The theory is in the form of a corporate theory where the hospital is the superior and the medical staff is the subordinate. This research shows that the hospital has implemented the theory and legislation which is then contained in policies which are implied to be the basic rules in handling medical disputes in the hospital. Furthermore, in subsequent studies, the same theories and other theories can be examined again as a reference to be set forth in an internal hospital policy.

\section{b. Managerial Implication}

Although it has been considered very effective in implementing laws and regulations regarding the responsibility of hospitals in the process of resolving medical disputes. However, there are still some things that have not been carried out properly, such as mediation that does not occur both internally within the hospital environment and also in the district court environment. In this case, because there was no agreement in the mediation, the lawsuit case continued for few years and the hospital had to attend it quite a few times. This is very time-consuming and labor-intensive, not to mention the costs that must be spent on financing lawyer partners. It feels better if medical disputes do not go to court but are resolved at the mediation stage, either in the hospital environment or in court with a peace deed. (Agung-RI, 2016)

In addition, the absence of funding for legal proceedings and compensation will have implications for the hospital's unpreparedness in the event of a medical dispute in an unexpected time. Even though the Hospital has indeed carried out an obligation for 
The Implementation Effectiveness Of Hospital Responsibility Towards Medical Dispute...

professional insurance, as well as providing a legal unit to provide an assistance and a sense of security to those involved in medical disputes, funds are still needed if an unfavorable decision occurs for the Hospital such as if the judge finally grants. the plaintiffs' lawsuit. Not to mention if a patient reports to the police, it will cost a lot of money, such as in terms of providing legal assistance to the health workers involved, as well as other costs. Therefore, the provision of funds for legal proceedings should also be considered by the hospital and not only relying on professional insurance.

\section{Conclusion}

There are several laws and regulations that can be a source of reference regarding the responsibilities of hospitals in the process of resolving medical disputes, including Law Number 36 of 2009 concerning Health, Law Number 44 of 2009 concerning Hospitals, Law Number 36 of 2014 concerning Health Workers, and Regulation of the Minister of Health of the Republic of Indonesia Number 4 of 2018 concerning Hospital Obligations and Patient Obligations. Therefore, it is hoped that the hospital board of directors can refer to these regulations regarding what the hospital must do in relation to the responsibility for medical personnel in the process of resolving medical disputes.

\section{Bibliography}

Agung-RI, M. (2016). Prosedur Mediasi di Pengadilan. Retrieved from JDIH Mahkamah Agung-RI: https://jdih.mahkamahagung.go.id/

Champion, D. J. (1981). Basic Statistic for Social Research. New York: Macmillan Publishing.

Handayani, T. (2014). Penyelesaian Sengketa Medis Melalui Mediasi Dihubungkan Dengan Peraturan Mahkamah Agung Nomor I Tahun 2008 Tentang Prosedur Mediasi di Pengadilan. Jurnal Hukum Mimbar Justitia, 6(2), 369-388.

Hidayat, A. A. (2007). Metode Penelitian Keperawatan dan Teknik Analisa Data. Jakarta: Penerbit Salemba Medika.

Kesehatan, K. (2018). Peraturan Menteri Kesehatan Nomor 4 Tahun 2018 Tentang Kewajiban Rumah Sakit dan Kewajiban Pasien. Retrieved from JDIH BPK RI: https://peraturan.bpk.go.id/

Kusumaningrum, A. E. (2016). Mediasi Dalam Penyelesaian Sengketa Medis Sebagai Upaya Perlindungan Pasien. Jurnal IImiah Hukum dan Dinamika Masyarakat, 14(1), 70-78. doi:10.36356/hdm.v14i1.445 
Moleong, J. L. (2007). Metodologi Penelitian Kualitatif. Bandung: PT. Remaja Rosdakarya. Njoto, H. (2011). Pertanggungjawaban Dokter dan Rumah Sakit Akibat Tindakan Medis yang Merugikan Dalam Perspektif Undang Undang No 44 Tahun 2009 Tentang Rumah Sakit. DiH: Jurnal Ilmu Hukum, 7(14), 57-71. doi:10.30996/dih.v7i14.263

Pemerintah. (2009). Undang-undang (UU) No. 36 Tahun 2009 Tentang Kesehatan. Retrieved from JDIH BPK RI: https://peraturan.bpk.go.id/

Pemerintah. (2009). Undang-undang (UU) No. 44 Tahun 2009 Tentang Rumah Sakit. Retrieved from JDIH BPK RI: https://peraturan.bpk.go.id/

Pemerintah. (2014). Undang-Undang (UU) No. 36 Tahun 2014 Tentang Tenaga Kesehatan. Retrieved from JDIH BPK RI: https://peraturan.bpk.go.id/

Trisnadi, S. (2017). Perlindungan Hukum Profesi Dokter Dalam Penyelesaian Sengketa Medis. Jurnal Pembaharuan Hukum, 4(1), 24-41. doi:10.26532/jph.v4i1.1656 